Insight, part of a Special Feature on Urban ecological and social-ecological research in the City of Cape Town

\title{
An Ecological View of the History of the City of Cape Town
}

\author{
${ }_{\text {Pippin M. L. Anderson }}{ }^{1}$ and Patrick J. O' Farrell $^{2}$
}

\begin{abstract}
Rapid global urbanization and the knowledge that ecological systems underpin the future sustainability and resilience of our cities, make an understanding of urban ecology critical. The way humans engage with ecological processes within cities is highly complex, and both from a social and ecological perspective these engagements cannot be interpreted meaningfully on the basis of a single timeframe. Historical analyses offer useful insights into the nature of social-ecological interactions under diverse conditions, enabling improved decision-making into the future. We present an historical review of the evolving relationship between the urban settlement of Cape Town and the ecological processes inherent to its natural surroundings. Since its establishment, the people of Cape Town have been acutely aware of, and exploited, the natural resources presented by Table Mountain and its surrounding wilderness area. An examination of this pattern of engagement, explored through an ecological process lens, in particular drawing on the terminology provided by the ecosystem services framework, reflects a journey of the changing needs and demands of a growing urban settlement. Ecological processes, and their ensuing flow of ecosystem services, have been exploited, overexploited, interrupted, reestablished, conserved, and variably valued through time. Processes of significance, for example water provision, soil erosion, the provision of wood and natural materials, and the role of fire, are presented. This historical analysis documents the progression from a wilderness to a tamed and largely benign urban environment. Evident is the variable valuing of ecosystem service attributes through time and by different people, at the same time, dependent on their immediate needs.
\end{abstract}

Key Words: ecological history; ecosystem services; City of Cape Town; social ecological systems

\section{INTRODUCTION}

A recent review of urban ecology research shows both a lack of and the misrepresentation of urban ecology research (Corbyn 2010). Not only do ecologists tend to avoid urban systems, but when they do work in them they are likely to misrepresent them. This suggests a lack of desire to engage in unique urban drivers, perhaps for their complexity and relative novelty (Corbyn 2010). In particular the way humans engage with ecological processes within cities is highly complex. With rapid global urbanization, with a predicted increase in the immediate urban footprint by $1,000,000 \mathrm{~km}^{2}$ by 2025 (McDonald 2008, Wilby and Perry 2006), research into urban ecology is now considered critical (Niamela et al. 2011, Pickett et al. 2008). In recent years an ecosystem services focus has emerged as a useful way to explore human-ecological interactions (MEA 2005). Ecosystem services (and disservices) are those ecological process end points that benefit human wellbeing. These have been divided into provisioning, regulatory, cultural and supporting services (MEA 2005).

Ecological systems, highlighted as underpinning our social fabric by the ecosystem services framework, are typically dynamic often following long-term cycles of succession and climax (Redham 2011). Both Holling and Gunderson (2002) and Walker et al. (2006) warn that no social-ecological system can be understood on the basis of a single time-shot. Whilst the ecosystem services research area has rapidly advanced in the last decade there is a conspicuous failure to consider longer temporal scales within these studies (Lyytimaki and Sipila 2009, Holling and Gunderson 2002, Walker et al. 2006). The past offers useful insights into the nature of social-ecological interactions under diverse conditions and elucidates the implications of decisions made (Costanza et al. 2007). This is in keeping with similar work by Barthel et al. (2010) who explore social ecological memory, building on the notion of collective social memory (Rothstein 2000), where adopting an historical analysis of people's engagements with the environment and ensuing ecological responses enables us to understand past engagements and actions and determine the implications for the environment (Barthel et al. 2010). This could in turn facilitate improved decision-making into the future (MEA 2005, Costanza et al. 2007, Redham 2011). There is also a marked paucity of ecosystem services research in the urban context, and none of substance that considers longer temporal scales (Lyytimaki and Sipila 2009).

We present an historical review of the evolving relationship between the urban settlement of Cape Town and the key ecological processes inherent to its natural surroundings. It draws on published historical works, read from an ecological perspective, and presents specific cases which serve to characterize the ecology of this developing city. We readily acknowledge the constraints of such an historical analysis which by nature must sit between social construct and historical fact (Barthel et al. 2000). We adopt an ecosystem 
services framework to tease out the dynamic relationship between people and this natural environment. In taking an historical view and focusing on the emergence of the City of Cape Town, it simultaneously contributes new material to the growing ecosystem services literature and expands our understanding of the ecology of cities. The City of Cape Town provides an ideal study area, given its relatively short and well documented history (Hall 2001, Hall 1993, Hall and Markell 1993), its geographic location on the tip of Africa a significant point on maritime trade routes, and its heterogeneous and extraordinarily rich ecology (Myers et al. 2000). In this review we present five discrete time periods relating to the city starting with transhumance use, to early Dutch exploitation, through to true colonization by the British, the establishment of Union and apartheid, and finally to post democracy city planning.

\section{PREHISTPRY: EARLY EXPLOITATION, MOBILITY, AND WILDERNESS}

Archaeological evidence shows that the broader area that is Cape Town today has been occupied for thousands of years, initially by the San who were hunter-gatherers who lived throughout the southern African continent (Mountain 2003). From the late Pleistocene there is evidence of manipulating and managing the environment in order to promote ecosystem service provision. The indigenous fynbos vegetation of the Cape is both fire-prone and fire-adapted and fire is an essential ecological driver for the persistence of the flora of this botanically diverse region (Le Maitre and Midgley 1992). Archaeological evidence suggests that prehistoric people used fire as an effective means of influencing the ecology of the natural environment to ensure the delivery of provisioning services (Richardson et al. 1992, Deacon 1983). Specifically, fire was used to encourage certain bulb species in a system of dedicated patch foraging for food provision (Deacon 1992, Richardson et al. 1992, Deacon 1976, Hall 1984). The territory occupied and used by each group of San people was handed down through a system of familial inheritance, resulting in long periods of ownership and geographical association (Mountain 2003). Stories, myths and legends which draw on familiar landscape serve as evidence the strong associations between people and their landscape (Chennells 2003, Mountain 2003).

There was a significant shift in emphasis regarding the use of the natural environment with the arrival of the Khoekhoen (semi-nomadic herders), in the Cape around 2000 years ago (Mountain 2003, Deacon 1983). The Khoekhoen bought herds of sheep and cattle with them, requiring considerably greater exploitation of natural resources in the form of grazing and water. The Khoekhoen took up the use of fire to stimulate grazing for their substantial herds (Deacon 1992). This was done on a far greater scale than practiced by the San. On passing the Cape in 1495, the Portuguese explorer Vasco da Gama, named it the 'tierra del fume', translated as land of smoke, in response to the billowing smoke he saw from fires from the mainland. While we cannot know if these were natural or intended fires, it entrenches the idea of the significance of fire as an ecological driver of this system, and one that certainly would have loomed large in the lives of those inhabiting the Cape (Luckhoff 1951).

There was conflict between the San and the Khoekhoen over provisioning services. The Khoekhoen herds were large, for example with a single herd of 20,000 sheep and cattle being recorded by settlers in 1652 (Luckhoff 1951). This herd is described as entirely denuding the area in which it was set to graze within a month (Luckhoff 1951) before being moved on as part of a large-scale transhumance pattern (Smith 1983). The use of extensive burning to stimulate grazing combined with the heavy grazing of these large herds reduced the available pasturage for wild game, in turn reducing wild game numbers. While the Khoekhoen kept livestock they seldom ate their cattle which had a cultural significance (Boden 2000) but preferred to support themselves, like the San, on hunted wild game. The San, faced with reduced area for gathering in response to large fires in areas not determined by them, and reduced available game for hunting, started to steal domestic livestock from the Khoekhoen and inevitable conflict ensued (Luckhoff 1951). One thousand five hundred years after the arrival of the Khoekhoen, while both groups were still present, the writings of early European settlers suggest that the Khoekhoen had clearly come to dominate (Luckhoff 1951). The few remaining San were assimilated into the Khoekhoen and thus the term Khoe-San emerges.

Reflections on the early history of human settlement in the Cape Town area show the significant use of fire as a means of manipulating the natural environment. For the San this was purely for provisioning purposes. The shift from San to Khoekhoen dominated occupation sees a change in both the scale and motivation of the use of fire from small areas to stimulate provisioning services to large areas for provisioning in order to support cultural aspects of life. The role of fire foregrounds the value of an historical reflection where elements of the functioning ecology, its drivers and effects are variably valued by different people, in this instance, at the same time.

\section{0 - 1700: EARLY SETTLEMENT, TAMING THE WILDERNESS}

During the $16^{\text {th }}$ and $17^{\text {th }}$ centuries trade between the Europe and Asia, primarily for silk and spice, became restricted by the dominance of the Ottoman Empire who controlled extensive territories that formed a barrier to trade. The need for an alternative route, via the sea, became critical. The sea route around Africa was long and unworkable without some place to stop to replenish supplies. Early attempts to navigate this without stopping for fresh water and produce saw whole crews lost to scurvy, giving rise to tales of unmanned ghost ships (Luckhoff 1951). What was needed was a site midway 
between Europe and the East, with abundant water, wood, wild game and the potential to grow fresh produce, to service passing ships. Examination of various options showed the Cape, already well known to European travelers, to be most favorable (Worden et al. 1998, Luckhoff 1951). After attempts by various groups at actual settlement and control, primarily foiled by the indigenous people, it was the Dutch East India Company, a powerful economic enterprise, who established a refreshment station at the Cape in 1652, under the command of van Riebeeck (Worden et al. 1998).

Herewith began an era of intense exploitation and overexploitation of ecological resources as early settlers set out to dominate and subdue the wilderness of the Cape (Hall 2001, Hall 2008). Perennial water is an unusual feature in the region and the perennial spring water emerging from the Table Mountain Group aquifer (February et al. 2004) at the Cape was the most significant resource, both to provision ships and to irrigate supply gardens (Brown and Magoba 2009). The significance of this perennial supply of the provisioning service is evident in the suggested name 'Camissa', meaning 'place of sweet water' which the Khoekhoen purportedly gave to the area immediately below Table Mountain which forms the present day City of Cape Town (Cape Town Partnership 2010).

Wood was heavily targeted by the Dutch for fortress construction, repair to ships, and for fuel for those occupying the refreshment station and for replenishing stores on passing ships (Luckhoff 1951). While the Fynbos on the front slopes of Table Mountain provided ample firewood from the larger woody Protea species, wood for building was less readily available. Forest patches of larger Afromontane species were found a little further inland, in ravines on Table Mountain (Hall et al. 1993, Wagener 1957, Laidler1939). In some instances outposts were established to secure these wood resources (Hall et al.1993). While there was some concern around the inaccessibility of many of the forest patches, at the outset van Riebeeck expressed delight at the apparently abundant wood resources (Hall et al. 1993, Burman 1976). However, exploitation of this provisioning service was rapid and intense and within six years of their arrival the Dutch East India Company put out a proclamation that there should be no further felling of yellow wood trees (Podocarpus sp.) (Bradlow 1994, Luckhoff 1951). Attempts to regulate tree cutting failed and only fifty years after the arrival of European settlers the slow-growing indigenous forests had been dramatically reduced such that recruitment was essentially interrupted (Simmons 1993). The depletion of wood reserves, and general degradation of the forests of the Cape, was not borne out of ignorance. A number of accounts show a detailed interest and awareness of the particular biology of plants. For example, as part of his fortification plan, van Riebeeck built a hedge out of the woody species Brabejum stellatifolium (Yeld 2004). This is a fast growing species that is readily propagated from fresh seed and forms a much branched tree described as ideal for a thick hedge. The overexploitation of the forests can only be attributed to a transitory mind-set aimed at maximum economic gain, rather than ecological ignorance.

At the outset the Dutch did not intend to keep livestock but only to barter for it. However, the transhumance lifestyle of the Khoe-San meant this was not always possible and they had to keep some livestock on a permanent basis (Skead 1980). Slowly these herds grew. Significant grazing exploitation on the part of the settlers only really happened with the granting of free hold land to 'free burgers'. This was as a result of the failure of the immediate settlement to generate adequate food for the Company members as well as passing ships. Company members were released from service and allocated land with the express purpose of supplying the Company. In an attempt to be viable these allocated farms tended to be large. Settlers attempted to emulate the farming practices of the Khoe-San and used fire to stimulate grass production for grazing. The nuances of fire frequency, intensity and season in the different Fynbos communities are understood to be significant determinants of community composition and persistence (Cowling et al. 1997). In conjunction with the large herds already present in the area, the confined nature of the free burger farms, and extensive areas burnt in runaway fires, too frequent fire intervals or with ill-timed accidental fires negatively affecting postfire recruitment, the beginnings of associated soil erosion and general environmental degradation were recorded (Deacon 1992, Kruger 1977, Taylor 1977).

While the refreshment station at the Cape was never intended as more than a temporary arrangement, there naturally emerged a cultural significance and sense of place. The control of such a site had economic and political significance. Recorded is the perceived preciousness of the provisioning station, the glorious ecosystem services provided, which made the Cape take on monumental proportions in the minds of those traveling by ship. An early traveler writes of the inability to capture the joy felt by the crew on the first sighting of Table Mountain after the long journey from Europe, he described how even those who could barely walk would crawl on to the deck to "catch a glimpse of the majestic mountain that guards the entrance to Table Bay" (Bradlow 1994). From early on the Cape was known as Cabo de Bona Esperance, translated as the Cape of Good Hope (Yeld 2004). If viewed in relation the constituents of wellbeing, the Cape represented personal security and health after months at sea with limited nutrition and exposure to considerable environmental risk and hazard. Given this sense of hope and curative opportunity presented, wrapped up as it was with spice and associated wealth, from the bundle of provisioning services presented by the Cape and a growing aesthetic and social engagement, a strong sense of place emerges and what would be termed cultural ecosystem services become evident. 
This engagement, where European settlers established a sense of belonging to this 'new' landscape and started to take a longer-term view of settlement, presented a considerable threat to the indigenous populations at the Cape. The over exploitation of resources by the settlers affected their own provisioning, and contestation arose, in particular over access to grazing. The growing sense of place, and ongoing and increased exploitation of natural resources by the settler population, translated into significant disservices for the resident Khoe-San population, with an erosion of personal wellbeing and safety (Rassool and Thorne 2001). This environment-driven engagement had serious human consequences. The local Khoe-San populations were dramatically weakened through the seizing and control of natural provisioning resources on which they depended. In writing on the San, Penn (1996) notes that the degree of connectivity to the land, which was "a profoundly spiritual connection between particular places and the system of meaning the San constructed in order to explain their world", such that to lose the land was to lose everything. In addition the Khoe-San were also exposed to new diseases. Most notable was the Small Pox epidemic of the early 1700s which had a dramatically high impact on the previously unexposed KhoeSan, reducing their numbers such that 1739 saw the last recorded resistance by the Khoe-San in the Cape (Crosby 1986). Through the dispossession of the indigenous people and reduced numbers through ongoing skirmishes and the introduction of disease, this era saw the attrition of the original inhabitants of the Cape (Rassool and Thorne 2001). Much long-term social ecological understanding is essentially lost in this process, with limited evidence of knowledge transfer. There is for example little archaeological evidence of slave communities at the Cape adopting indigenous practices in environmental engagement in, for example, hunting or gathering practices (Markell et al. 1995).

To the Dutch the abundant wild animals at the Cape made for a particularly hostile environment for settlement. In tracking the ecology of imperialism, Crosby (1986) notes that fifty years after the introduction of the horse to South Africa, the horse population numbered a mere 900 . By contrast half a century after horses were put ashore in the pampas of South America the total numbers were more than could be counted. An early traveler to the Cape wrote, "This remotest part of Africa is very mountainous, over-run with wild beasts, as lions, tigers, wolves and many other beasts of prey...". In his diary in 1656 van Riebeeck tells of a case where a lion pushed open the door of a house and took a dog from within (Wagener 1957). These trials were not limited to the Dutch settlers. In 1609 a Dutch sea captain wrote of the Khoe-San managing the lion populations, saying "there are many lions here, against which they sometimes wage war" (Skead 1980). The noted ability of indigenous people to assist in the healing of bites from wild animals points to a familiarity with the challenges of sharing an environment with dangerous animals (Skead 1980). In 1656, just four years after the establishment of the refreshment station by the Dutch East India Company, a bounty was placed on all large carnivores (Skead 1980). This saw the start of the systematic extermination of these animals from the area of settlement, later to become the City of Cape Town. This formed part of the process of what is termed 'simplification', where key elements of the environment are removed making a more benign environment that can be controlled for human settlement (Simmons 1993). The beginning of the removal of apex predators would have had significant implications for the functioning ecology of the Cape Town area. While wild animals were primarily perceived as an ecosystem disservice, there was also a culture of hunting, not only for the provision of food, but also for pleasure: what would in contemporary terms be recognized as a cultural ecosystem service (Skead 1980).

The Varsche River running off the front face of Table Mountain was canalized almost immediately in a series of canals, or 'grachte' in an ordered grid to facilitate its utilization (Hall 2008). These saw water put to use, taken variously through the Company mills at the base of the Mountain, through wash houses, on to irrigate the Company gardens, past the main fortification and dwelling places, and out to sea or to supply ships in the bay. This 'ordering' of nature no doubt fueled a sense of control in an otherwise alien world, and served as part of the process of taming and simplifying the natural environment (Hall 2008, Simmons 1993). In 1655 some sailors took ill from water taken on board at the Cape, and the first environmental legislation was put in place in an attempt to prevent people from fouling the water supply higher up stream (Brown and Magoba 2009).

This era sees a shift in ownership and use of key environmental resources. While European settlement remained small, the settlement was aimed at extracting maximum benefit from the environment and the associated environmental impact was significant (Deacon 1992). Extraction of provisioning services was matched to a far greater population than that of the immediate Company members posted at the Cape, servicing large numbers of passing traffic. It is in this early establishment phase that we see the start of the eradication of ecosystem disservices, and a shift to a typically benign urban environment. We sense the early Dutch East India Company wrestling with various elements of the natural environment, ordering and controlling those they could. These environmental engagements demonstrate the recursive relationship between society and the environment, where people express their identity through environmental manipulation and management, and the environment in turn shapes the identity of those who live in it (Hall 2006). 


\section{0 - 1800: SETTLEMENT, CONTINUED OVER- EXPLOITATION}

Cape Town was increasingly seen as the gateway to southern Africa and the ample resources found here, as well as being strategically positioned in a global map of growing colonization. The opportunities and services presented by Cape Town were numerous and the Dutch faced considerable pressure to relinquish their role to other colonial forces. While the wilderness was viewed as bountiful, and strategically placed, successful, productive farming at the Cape took a while to establish. While the natural environment provided, taming this environment for production services proved difficult. The Company offered more land to 'free burghers' in the hope that this would improve the production of grain and other staples. However, the harsh prevailing south-easterly winds in summer, long dry summers, highly acidic and comparatively infertile soils, ongoing predation of livestock by wild animals, and repeated stock theft all hindered farming activities (Laidler 1939, Cowling et al. 1997). Combined with a lack of secure tenure and restrictions imposed on competitive trading by the Dutch East India Company there was little incentive to make much effort in farming beyond meeting basic obligations. Records from the late 1600 s tell us that the Company had to hand out rice to the poor suggesting people were unable to feed themselves, and that there was not enough locally grown produce (rice has never been grown at the Cape) to meet the needs of the settlers (Worden et al. 1998). However, as the town grew, there was greater demand and productivity increased to meet that demand. Fifty years of learning appropriate farming techniques to meet the particular abiotic environment of the Cape, combined with considerable manpower, where every settler had numerous slaves, meant farming finally started to flourish.

After more than fifty years of intense harvesting of resources from natural ecosystems to fuel trade between Europe and the East, and Dutch East India Company profits, the settlement of Cape Town was showing signs of extensive environmental degradation. What wood was left continued to be depleted. By the early 1700s the broader Cape Peninsula ceased to be a source of timber (Hall et al. 1993, Luckhoff 1951). The visiting Swedish naturalist Thunberg commented in 1772 that no forests could be found within the vicinity of the Cape Town except within a few inaccessible gorges (Luckhoff 1951, Burman, 1976). A household inventory in the late 1700s notes that for sufficient wood to run a well-to-do household in Cape Town, two slaves, dedicated to daily wood collection, were required (Ross 1984). The denudation of vegetation on the mountain side saw the start of considerable soil erosion washed down the slopes and into the sea. This was of a magnitude that meant the quay had to repeatedly be lengthened (Sparrman in Worden 1998). By the mid-1700s very little wild life remained in the town and even baboons were a rare sight. Archaeological inventories of bones found around dwellings in the Cape reflect this in fewer and fewer contributions of wildlife to local diet through time (Hall et al. 1993). While wildlife was still fairly abundant on the flats beyond Cape Town, hardly any game could be found for a 20 mile radius around the main fortification of the Castle (Skead 1980). Indeed, in 1720 Johanna van Riebeeck, the granddaughter of the first commander of the Cape, passed through the Cape and described Cape Town as looking "far prettier and more pleasant from the sea than it does when you are on land. It is a miserable place. There is no grass ... There is nothing pretty to be seen along the shoreline ..." (Bosman 1952).

Despite an attrition of numerous ecosystem services following intense use, the sense of place and association, and an emerging essence of what constitutes 'Cape Town', continued to grow. In the 1700s a climb to the top of Table Mountain was considered obligatory for visitors (Worden et al. 1998). Those very winds that so frustrated the farmers, were sought out by seasonal visitors from India, who named the wind the 'Cape Doctor' for the sense of relief it gave after the oppressive heat of India (Worden et al. 1998). Generally, sedentarization results in a strong psychological and cultural attachment to where people live (Redham 2011), and we see growing association on the part of the settlers between the environment and a cultural sense of place and belonging (Hall 2008).

The relatively arid nature of the Cape Town area was recognized early on, with the first serious water shortage experienced in 1663 (Brown and Magoba 2009). By 1731 the population of Cape Town was well over 3000 and there were growing water demands and increasing pressure on drainage and effluent removal. Rubbish was generally broadcast or thrown in river systems (Markell et al. 1995). Some efforts were made to improve the canals that serviced the town and pipes were introduced to carry water to the jetty and for pumps in the town for when the canals ran dry. However, the Company was reluctant to invest heavily (Brown and Magoba 2009) and this period saw extensive use and degradation of water supplies.

This era of intensified settlement saw the over exploitation of provisioning services and in some instances the interruption or even elimination of regulating services in places evident for example in recorded soil erosion. The pursuit of a typically benign environment for urban settlement was achieved in many respects, for example with the removal of wild animals from the urban settlement. Water was heavily exploited in the 1700 s to meet growing urban demands, and little effort to manage the water resources saw their general decline. Ongoing efforts to tame and manage the natural environment, in particular with respect to productive farming were difficult, but through the 1700s agriculture finally became a successful endeavor. 


\section{0 - 1900: FORMAL COLONIZATION, LARGE SCALE ENVIRONMENTAL EXTRACTION}

The British had significant interests in the East and Australia and the position of the Cape meant it became an ever more appealing piece of land to hold. After ongoing and significant clashes the Dutch Cape Colony formally became British territory in 1814 (Butlin 2009). This change in governance saw a shift in the nature of Cape Town. A population figure from 1829 puts the number of residents in Cape Town at 18,296 (Phillips 1984). A big contributor to this increased population was the influx of English merchants involved in the export of raw material (Phillips 1984). While still highly relevant as a port and refreshment point between Europe and their colonial interests in the southern hemisphere, the Cape was also seen as a noteworthy source of raw materials and produce (Butlin 2009). To expedite the movement of produce from the interior to the port, in 1828 the previously crude and dangerous pass over the mountains out of Cape Town was put under proper construction. As part of a colonial enterprise Cape Town was now exposed to a far greater economic market. The 1800 s saw considerable growth in wheat and wine production and livestock husbandry. While much of this continued to be produced in the immediate proximity of the town, there was a rapid expansion of farm land beyond the original free burgher farms. While the start of the $19^{\text {th }}$ century saw a shift in governance and associated important cultural and economic changes for Cape Town, the end of this century saw yet another revolution: the discovery of diamonds in 1867 and gold in 1886. While considerably beyond Cape Town, these two discoveries served to move Cape Town from a small colonial port town to a flourishing economic center.

This growth in population at the start of the $19^{\text {th }}$ century saw the settlement of Cape Town for the first time really move outside the original boundaries laid out by the Dutch 150 years earlier. Small suburbs started to emerge outside the town. Most of the original farms in what is Cape Town today were still mortgaged and while several farms remained intact for longer, this expansion saw a rapid division of some of this land as this was sold off for housing (Laidler 1939). For example the farm Leewenvoet, which had previously supported 80,000 vines, was sold off for residential development (Laidler 1939). This expansion in urban footprint, with increase in demand for produce, saw the simultaneous expansion of the farming footprint beyond the town. In the town itself occupation was dense and there was considerable subletting (Rassool and Thorne 2001). With the abolition of slavery at the Cape in 1834 several previous slave owners used their compensation to enter the property market, providing leases to freed slaves who now sought accommodation (Rassool and Thorne 2001). In 1840 the first municipality was formed, dividing the town into districts for governance purposes. Increased densification in the town, combined with better roads and ultimately rail and tramways, saw a move towards homesteads, or country houses, held by the wealthy outside Cape Town. Real estate advertisements marketed these areas on the basis of what is now perceived as a regulating service; claiming 'clean air' in the suburbs away from the center of town where evidently the air was extremely polluted (Wagener 1957). The provision of water with the rapid growth of the town became a pressing issue, and shortages were experienced regularly. This saw the construction of a series of reservoirs in and around the town. With growing demand ever bigger reservoirs were built, most significantly at the end of the century, a series of dams on Table Mountain (Brown and Magoba 2009).

Cape Town itself in the 1800 s was not the most salubrious environment. Much of the infrastructure of the original settlement had remained unchanged over the previous century and a half and the growing population started to put strain on these old artifacts. Many of the streets lacked sewers and the grachts were heavily polluted; these being used for all and any purpose quickly became clogged (Phillips 1984, Brown and Magoba, 2009). Cleaning of the grachte fell to the Superintendent of Police and was not considered a priority (Phillips 1984). Visitors described Cape Town as extremely unhealthy. The shambles presented another significant source of environmental pollution. After slaughter offal was traditionally dumped at sea at high tide (Phillips, 1984). The volume of waste with the increased population meant that as the tide retreated much of this was left rotting on the beach, presenting a highly problematic waste hazard. Where the surrounding natural environment had absorbed and processed waste in the past, the rapid increase in population numbers put excessive pressure on these regulating services which could no longer process the volumes produced. Moves to improve the environment of the town did help matters. The grachte for example were enclosed in this period (Phillips, 1984), and in 1890 a city-wide drainage and sewerage scheme was implemented. Evident here is an example illustrating the contemporary notion of paying for replacing ecosystem services, an idea which underpins much of the arguments supporting ecosystem service preservation today (de Wit et al. 2009).

Following the early over exploitation of wood in the Cape, the 1800s saw significant afforestation to meet both growing colony needs and for export. This need for wood, combined with exposure to other colonized areas, saw the introduction of alien plant material (Alston and Richardson 1996). Towards the end of the 1800s significant forestry was pursued, largely with Pine and Eucalyptus species on state, local authority and private lands. In addition to the supply of wood, there was a strong belief that afforestation would improve water supply through driving local climates and increasing rainfall, suppressing fire and generally improving the aesthetics, in particular of Table Mountain (Shaughnessy 1980). In 1896 Acacia species were also planted on the face of the mountain to obscure a view onto an access road across the slopes 
(Shaughnessy 1980).The plantation of alien forestry is described as helping rationalize a landscape according to principles of a global political economy (Hornborg et al 2007) and this speaks to the idea that Cape Town formed part of a larger, global economic endeavor. In the immediate proximity to Cape Town forestry failed. Lower rainfall and hot dry summers with fierce south-easterly winds meant these forests of fire-prone species burnt repeatedly and were never commercially viable (Botes personal communication). These interventions sought to promote a foreign aesthetic based on an assumed ecology from the woodier landscapes of Europe, and were ecologically grossly misguided, further degrading the natural environment of Cape Town.

Australian Acacia species were introduced to stabilize the mobile sands on the dune fields to the north and east of Cape Town, known as the Cape Flats. These sands had been considered a significant ecosystem disservice from the earliest times of settlement. They proved particularly difficult to cross with cattle, evident in occasional vegetated dune slacks marked up on early maps as sites where cattle could traverse these dunes (Wagener 1957). These Acacia species, having evolved in a Mediterranean fire-prone environment, thrived at the Cape in the absence of their natural controls and have since become problematic invasive species posing considerable threats to local biodiversity (van Wilgen 2012). The use of alien plant species to manage the natural environment shows a manipulation of a perceived ecosystem disservice or the lack of a regulatory service, based on provisioning requirements of the time.

With the expanding urban footprint there was an early recognition in this era of the need to set aside tracts of land. The Forest and Herbage Preservation Act no 18 of 1859 made provision for the protection of forests and indigenous vegetation, and to prevent deliberate fire setting (Grove 1987). However, this failed to take purchase during the colonial era as the market demand driving the engagement with the environment was intense and private land owners continued deforestation to meet these demands and grow their own personal wealth. The setting of this Act shows a shift in sentiment, if not in action.

The colonial era of the 1800s placed Cape Town as a major port in the network of colonial interests, in particular in the southern hemisphere. In response to this there was a dramatic increase in population and expansion of the urban footprint. Provisioning services were heavily utilized to supply larger colonial entities, and is evident in the collapse of some previously functioning natural regulatory services in response to population pressure and poor management. The organization and manipulation of the environment through this colonial period, in particular through afforestation, has had cataclysmic consequences for the globally important biodiversity of the region.

\section{0 - PRESENT: UNION TO DEMOCRACY, FOOTPRINT BEYOND THE CITY}

1910 saw the Union of South Africa with the amalgamation of four separate territories. The Union was a British dominion, governed under a form of constitutional monarchy which lasted until 1961 when South Africa became a Republic. The 1900s saw considerable population growth and the carving up and segregation of the City along racial lines. Using health as a justification following an outbreak of bubonic plague in 1901, black Africans were moved out of portions of the City to the outskirts (Rassool and Thorne 2001). This was the first forced removal and set a pattern for future residential segregation along racial lines. These racially motivated residential arrangements placed non-white people on the urban edge. If one takes the argument of the promotion of urbanization as one of taming the wild and making a more benign environment, then the urban edge is the frontier of this endeavor and must therefore be the most hostile environment. Certainly in the case of Cape Town, the peripheral Cape Flats exposed, and continues to expose, residents to harsh winds, flooding due to high water tables, and large volumes of dust from mobile sands. Certainly these areas are less proximate to the recreational and cultural (and associated work) opportunities presented by Table Mountain. The Cape Flats have numerous ecosystem disservices. There can be little confusion around the fact that apartheid spatial planning took an informed view and disadvantaged certain people by placing them in uncontrollable, untamed, and difficult ecologies.

In 1902 Ebenezer Howard published Garden Cities of Tomorrow, which expanded on the growing idea of a planned city based on scientific and economic principles, emerging in response to the rapid and organic growth of cities in Europe with the industrial revolution (Ebenezer et al. 1946). The idea was the creation of new towns where their development could be predetermined and controlled. This notion was adopted in planning the City of Cape Town between the 1920s and 1940s and several suburbs were designed along these lines (Rassool and Thorne 2001). This model spoke to the notion of taming wild nature for human settlement and urbanization, but acknowledged the importance of the green space for the "full development of man's moral and spiritual qualities" (Ebenezer et al. 1946). The benefits of a rural and agrarian lifestyle were acknowledged and these garden cities were planned with close proximity to permanent bands of agricultural land, where a natural or at least green environment is seen as an important part of the City.

While in the early 1900s the lower slopes of Table Mountain, immediately above the City were still grazed (Adamson 1931), this utilitarian and purely provisioning view of urban green space started to shift. Table Mountain was first formally acknowledged as an asset to the City in 1951 with the van Zyl Commission which was established to draw up recommendations for the preservation of Mountain. On the 
basis of these recommendations Table Mountain was declared a National Monument (Hey 1978). This positioned Table Mountain under the National Monuments Council, suggesting a predominant cultural recognition at this time, over the ecological. An inspection of the Board members shows a pleasing spread of national, provincial and civic interest. However, it is important to note that board membership also reflected the then minority white rule, showing conservation to be in the hands of and nominally a white interest (Rosenthal 1966).

Early conservation efforts, focused as they were on Table Mountain, are notable for several reasons. Table Mountain has always held an iconic value, initially perhaps as symbolic of the succor afforded by the Cape, then through notions of nature and romance emerging in the nineteenth century (Hall 2008), and now as symbolic of the City itself; evident in its repeated and caricatured use in the tourism marketing of the City. Early recognition of the importance and value of mountain catchments for water management placed Table Mountain ahead of other areas in terms of conservation awareness and effort (Le Maitre et al. 1996). The topography of Table Mountain meant it was not an option for urbanization. While there were efforts at the start of the twentieth century to ensure the urban footprint did not encroach on the Mountain, in reality much of the Mountain is off limits due to its sheer elevation and aspect. While the biodiversity of Table Mountain is significant (Trinder-Smith et al. 1996), it is in many regards the low-hanging fruit of the conservation agenda for the City. Our current understanding of biodiversity shows the lowlands of the City of Cape Town to hold significant remnants of both diverse and endemic vegetation types and flora (Rebelo et al. 2011, Cowling et al. 1997), which come under constant pressure from the growing footprint of the City. This conservation challenge falls to the City of Cape Town and recent work in this regard has seen the formation of the Biodiversity Network (City of Cape Town 2009, Holmes et al. 2012).

Today Cape Town has the same social and development discrepancies prevalent in other South Africa cities following its racially separatist and unjust history. The result is a population with diverse and often divergent needs, and the environment is variably used by Cape Town's population. Natural areas in the City are used for: religious and ceremonial purposes (for example male Xhosa initiates must spend time in the wilderness), natural resource harvesting (Petersen et al. 2012), recreation, and there are still considerable herds of cattle which graze within the City limits (Lannas and Turpie 2009). There is also a need to meet development and housing needs and the remaining green space in Cape Town comes under pressure (Holmes et al. 2012). There is a clear understanding now that social sustainability requires quality public open space (Southworth 2010), readily available in the City's urban conservation areas. As much as ever the state of the City's ecology and the wellbeing of its society are entwined. What is new is a budding understanding of the interwoven nature of these two issues and a new social-ecology of the urban is emerging (Niamela et al., 2011).

Some environmental issues persist. For example invasive alien plants continue to spread at the expense of ecosystem services and biodiversity (van Wilgen 2012). These are now met with novel and modern responses. For example the clearing of alien plants is now part of the hugely successful Government Public Works Programme: Working for Water. This project is iconic of successful environmental engagement in democratic South Africa, based as it is on the ecosystem service of improved water delivery while simultaneously speaking to issues of poverty alleviation and conservation (Turpie et al. 2008). Some environmental problems are getting worse. For example the provisioning of water for the City remains an ongoing challenge. Most of Cape Town's water now comes from outside the City, and having exhausted most natural surface water options in the region, the emphasis in terms of provisioning is now turning to the social dimension of resource and demand management (Brown and Magoba 2009).

Some new environmental issues are emerging such as climate change, which pose significant threats to the City. The City of Cape Town's Biodiversity Management Branch is pushing biodiversity conservation as the 'first line of defense' against these future threats. The ecosystem services argument in this context is a useful one and recognized as such by the City who are pushing for a vision of ecosystem and human wellbeing as one entity (O'Farrell et al. 2012). Ecosystem services provided by natural, functioning ecosystems and their biodiversity underpin the City's Integrated Development Plan and are specifically mentioned in two of the seven strategic areas: striving for sustainable urban infrastructure and services (conservation of natural resources, implemented in order to reduce flooding impact on livelihoods and regional economies, conserve biodiversity and improve living environments through greening, education and access, and safeguard human health and maintain recreational quality); and in the development of integrated human settlements (develop and maintain public open spaces).

\section{CONCLUDING POINTS}

This historical analysis tells a story of the progression from a wilderness to a tamed and largely benign environment. We also see a significant journey in relation to provisioning services. Here we see a shift in emphasis from grazing, to timber extraction to cultivation. Initially the immediate environment fails to provide adequately for any settled community of a certain size. The Khoekhoen adopted a transhumance lifestyle to ensure year-round provisioning and the initial Dutch settlers depended for a while on external supplies. With the management and manipulation of the natural environment there is a shift to provisioning from the 
immediate surrounds where crops and fruits are grown on the slopes of Table Mountain. With an increase in settlement population numbers and the value of land for urban settlement and dwelling sees a change in the pattern and scale of engagement with basic provisioning moved to beyond the City boundary. This is partly also in response to the collapse of some of these services in the City. This points to the danger of viewing the City as a bounded entity, but one where we need to consider flows on a much broader scale to understand what ecosystem services are being outsourced beyond the City and at what expense. These are initially provisioning services, and later certain cultural services. Within the City, the emphasis shifts to regulating services which increasingly we recognize as minimizing hazards and preserving both life and property. While this is the dominant model we also see a contemporary development disparity and an associated spectrum of wealth where a number of poorer people in Cape Town still use the immediate surrounding natural areas for provisioning services. Modern Cape Town has a diverse population using the full basket of ecosystem services available in the City.

What this historical review makes evident is the different value placed on ecosystem service attributes through time and by different people, at the same time, depending on their needs at the time. In terms of using an ecosystem services framework to inform future management this work serves to highlight the importance of these varying views. The very nature of the ecosystem services framework, hinged as it is on a human engagement with the environment, facilitates the identification of these variable social perceptions. This reflection also suggests tradeoffs will be necessary, and these will not always be easy.

The reality of social-ecological systems is that there are multiple solutions to any environmental engagement and these will vary depending on the dominant value system in place at the time (Adams 1996). Just as history shows us that varied perceptions through time may require tradeoffs in management, we also see that the dominant value system in control will determine who has access to what and how this is managed (Redham 2011). It is now acknowledged that explicit attention needs to be paid to the normative values of society and the parties involved but how to rank these remains the challenge (Niamela et al. 2011). We need to ask who bears the cost of a solution. Historically this has been the politically and economically weak, as evident in the ecologies experienced in the spatial geography of Cape Town. To address these issues does not require scientific insight, but political agility and willpower (Redham 2011).

Responses to this article can be read online at: http://www.ecologyandsociety.org/vol17/iss3/art28/ responses/

\section{Acknowledgments:}

This paper is a product of the Urban Ecology CityLab which is part of the CityLab programme of the African Centre for Cities at the University of Cape Town. The African Centre for Cities' CityLab programme is funded through the Mistra Urban Futures network (which is funded by Mistra the Foundation for Strategic Environmental Research and the Swedish International Development Cooperation Agency), the Provincial Government of the Western Cape (Department of Human Settlements) and the City of Cape Town.

\section{LITERATURE CITED}

Adams, W. M. 1996. Future nature: a vision for conservation. Earthscan, London, England. U.K.

Adamson, R. S. 1931. The plant communities of Table Mountain: II. Life-form dominance and succession. Journal of Ecology 16:135 - 143. http://dx.doi.org/10.2307/2255824

Alston, K. P. and D. M. Richardson. 2006. The roles of habitat features, disturbance, and distance from putative source populations in structuring alien plant invasions at the urban/ wildland interface on the Cape Peninsula, South Africa. Biological Conservation 132(2):183-198. http://dx.doi.org/10 .1016/j.biocon.2006.03.023

Barthel, S., C. Folke, J. and Colding. 2000. Social-ecological memory in urban gardens - Retaining the capacity for management of ecosystem services. Global Environmental Change 20:255-265. http://dx.doi.org/10.1016/j.gloenvcha.20 $\underline{10.01 .001}$

Brown, C. and R. Magoba. 2009. Rivers and wetlands of Cape Town: caring for our rich aquatic heritage. Water Research Commission, Pretoria, South Africa.

Bradlow, E. 1994. Human history of Table Mountain. in D. Hey (editor) The mountain: an authoritative guide to the Table Mountain Chain. Tafelberg, Cape Town, South Africa.

Boden, G. 2000. Kxoe material culture: aspects of change and its documentation. University of Cologne, Cologne, Germany.

Bosman, D. B. 1951. Briewe van Johanna Maria van Riebeeck en ander Riebeeckiana. Noord-Hollandsche uitgevers vir die skrywer. Amsterdam, The Netherlands

Butlin, R. A. 2009. Geographies of empire: European empires and colonies c. 1880 - 1960. Cambridge University Press, Cambridge, U.K.

Burman, J. 1976. The Bay of Storms: Table Bay 1503 - 1860. Human and Rousseau, Cape Town, South Africa. 
Chennells, R. 2003. The San of southern Africa: heritage and intellectual property. WIMSA, Windhoek, Republic of Namibia.

City of Cape Town. 2009. Environmental resource management department - biodiversity management branch: strategic plan 2009 - 2019. City of Cape Town, Cape Town, South Africa.

Corbyn, Z. 2010. Ecologists shun the urban jungle. Nature News. http://dx.doi.org/10.1038/news.2010.359 accessed 10 October 2010.

Costanza, R. L. W. Graumlich, C. Steffen, J. Crumley, K. Dearing, R. Hibbard, C. Leemans, D. Redman, and D. Schimel. 2007. Sustainability or collapse: What can we learn from integrating the history of humans and the rest of nature? Ambio 36:522-527. http://dx.doi.org/10.1579/0044-7447(2007) 36[522:SOCWCW]2.0.CO;2

Cowling, R. M., D. M . Richardson, P.J. and Mustart. 1997. Fynbos. in R. M. Cowling, D. M. Richardson, and S.M. Pierce (editors), Vegetation of Southern Africa. Cambridge University Press, Cambridge, U.K.

Crosby, A. W. 1986. Ecological imperialism, the biological expansion of Europe 900 - 1900. Cambridge University Press, Cambridge, U.K.

Deacon, H. J. 1983. The peopling of the Fynbos Region. in $\mathrm{H}$. J. Deacon, Q. B. Hnedey and J. J. N. Lambrechts (editors) Fynbos palaeoecology: a preliminary synthesis. South African National Scientific Programmes, Report 75. CSIR, Pretoria, South Africa.

Deacon, H. J. 1976. Where hunters gathered: a study of Holocene Stone Age people. South African Archaeological Series, 1. Cape Town, South Africa.

Deacon, H. J. 1992. Human Settlement. in R.M. Cowling (editor) The ecology of Fynbos: nutrients, fire and diversity. Oxford University Press, Cape Town, South Africa.

De Wit, M., H. van Zyl, D. Crookes, J. Blignaut, T. Javiva, V. Goiset, and B. Mahumani. 2009. Investing in natural assets. A business case for the environment in the City of Cape Town. Technical Report for the City of Cape Town, Cape Town, South Africa.

February E. C., W. R. Taylor, and R. Newton. 2004. Will water abstraction from the Table Mountain aquifer threaten endemic species? - A case study at Cape Point, Cape Town. South African Journal of Science 100(5-6):253-255.

Grove, R. 1987. Early themes in African Conservation: the Cape in the nineteenth century. in D. Anderson, and R. Grove (editors). Conservation in Africa, people, policies and practice. Cambridge University Press, Cambridge. U.K. http: //dx.doi.org/10.1017/CBO9780511565335.004
Hall, M. 1984. Man's historical and traditional use of fire in South Africa. in P. Booyse, and N.M. Tainton (editors). Ecological Effects of Fire in Southern African Ecosystems. Ecological Studies, Analysis and Synthesis, 48. SpringerVerlag, Berlin, Germany.

Hall, M. 1993. The archeology of colonial settlement in southern Africa. Annual Review of Anthropology 22:177-200. http://dx.doi.org/10.1146/annurev.an.22.100193.001141

Hall, M. and A. Markell. 1993. Historical Archaeology in the Western Cape. Goodwin Series 7:3-7.

Hall, M., A. Malan, S. Amann, L. Honeyman, T. Kiser, and G. Ritchie. 1993. The archaeology of Paradise. Goodwin Series 7:40-58. http://dx.doi.org/10.2307/3858077

Hall, M. 2001. Social archaeology and the theatres of memory. Journal of Social Archaeology 1:50-61. http://dx.doi.org/10.1 $\underline{177 / 146960530100100104}$

Hall, M. 2006. Identity, memory and countermemory. Journal of Material Culture 11:189-209. http://dx.doi.org/10.1177/13 59183506063021

Hall, M. 2008. The secret lives of houses: women and gables in the eighteenth century Cape. Social Dynamics: A journal of African studies 20(1):1-48. http://dx.doi.org/10.1080/0253 $\underline{3959408458560}$

Hey, D. 1978. Report on the future control and management of Table Mountain and the Southern Peninsula Mountain Chain. Government Printers, Pretoria.

Holling, C. S. and L. H. Gunderson. 2002. Resilience and adaptive cycles. in L. H. Gunderson and C. S. Holling. (editors). Panarchy: understanding the transformations in human and natural systems. Island Press, Washington D.C., U.S.A.

Holmes, P. M., A. G. Rebelo, C. Dorse, and J. Wood. 2012. Can Cape Town's unique biodiversity be saved? Balancing conservation imperatives and development needs. Ecology and Society 17(2): 28. http://dx.doi.org/10.5751/ES-04552-170228

Hornborg, A., J. R. McNeill, and J. Martinez-Alier. 2007. Rethinking environmental history: World system history and global environmental change. Globalization and environment series. AltaMira Press, UK.

Howard, E. 1902. Garden Cities of Tomorrow. Swann Sonnes Chien and Company. London. U.K. Ebenezer, H., F. J. Osborne, and L. Mumford. 1946. Garden Cities of Tomorrow. Faber, London, England, U.K.

Kruger, F. J. 1977. Ecology of Cape Fynbos in relation to fire. in H.A. Mooney, and C.E. Conrad, editors. Proceedings of the Symposium on the Environmental Consequences of Fire and 
Fuel Management in Mediterranean Ecosystem. USDA Forest Service General Technical Report, WO-3, U.S.A.

Laidler, P. W. 1939. The Growth of Government of Cape Town. Unie-Volkspers, Cape Town, South Africa.

Le Maitre, D. C., B. W. van Wilgen, R. A. Chapman, and D. H. McKelly. 1996. Invasive plants and water resources in the Western Cape Province, South Africa: Modeling the consequences of a lack of management. Journal of Applied Ecology, 33(1):161-172. http://dx.doi.org/10.2307/2405025

Le Maitre, D. and J. Midgley. 1992. Plant Reproductive Ecology. in R.M. Cowling, (editor). The Ecology of Fynbos: Nutrients, Fire and Diversity. Oxford University Press, Cape Town, South Africa.

Luckhoff, C. A. 1951. Table Mountain: Our Natural Heritage after Three Hundred Years. Balkema, Cape Town, South Africa.

Lyytimaki, J. and M. Siplia, 2009. Hopping on one leg - The challenge of ecosystem disservices for urban green management. Urban Forestry and Urban Greening 8(4):309315. http://dx.doi.org/10.1016/j.ufug.2009.09.003

Markell, A., M. Hall, and C. Schrire, 1995. The historical archaeology of Vergelegen, and early farmstead at the Cape of Good Hope. Society for Historical Archaeology 29(1):1034.

McDonald, R. I. 2008. Global urbanization: can ecologists identify a sustainable way forward? Frontiers in ecology and the environment 6(2):99-104. http://dx.doi.org/10.1890/070038

Millennium Ecosystem Assessment (MEA). 2005. Ecosystems and Human Well-being: Biodiversity Synthesis. World Resources Institute, Washington DC

Mountain, A. 2003. The first people of the Cape. David Philip, Cape Town, South Africa.

Myers, N., R. A. Mittermeyer, G. A. Fonseca, and J. Kent. 2000. Biodiversity hotspots for conservation priorities. Nature 403:853-858. http://dx.doi.org/10.1038/35002501

Niamela, J., J. Breuste, T. Elmqvist, G. Guntenspergen, P. James, and N. MacIntyre. 2011. Introduction. in J. Niamela, J. Breuste, T. Elmqvist, G. Guntenspergen, P. James and N. MacIntyre, (editors). Urban Ecology: Patterns, Processes and Applications. Oxford Biology, Oxford, U.K.

O'Farrell, P. J., P. M. L. Anderson, D. C. Le Maitre, and P. M. Holmes. 2012. Insights and opportunities offered by a rapid ecosystem service assessment in promoting a conservation agenda in an urban biodiversity hotspot. Ecology and Society 17(3):27. http://dx.doi.org/10.5751/ES-04886-170327
Penn, N. 1996. 'Fated to perish': the destruction of the Cape San. in P. Skotnes, (editor). MISCAST. Negotiating the Presences of the Bushmen. University of Cape Town Press, Cape Town, South Africa.

Phillips, H. 1984. Cape Town in 1829. In C. Saunders and H. Phillips, editors. Studies in the History of Cape Town, Volume 3. Centre for African Studies, University of Cape Town, Cape Town, South Africa.

Petersen, L. M., E. J. Moll, R. Collins, and M. T. Hockings. 2012. Development of a compendium of local, wild-harvested species used in the informal economy trade, Cape Town, South Africa. Ecology and Society 17(2): 26. http://dx.doi.org/10.57 $\underline{\text { 51/ES-04537-170226 }}$

Pickett, S.T.A., M.L. Cadenasso, J. M. Crove, P.M. Groffman, L.E. Band, C.G. Boone, W.R. Burch, C.S.B. Grimmond, J. Hom, J.C. Jenkins, N.L. Law, C.H. Nilon, R.V. Poyat, K. Szlavevecz, P.S. Warren, and M.A. Wilson. 2008. Beyond urban ledgends: an emerging framework of urban ecology, as illustrated by the Baltimore ecosystem study. BioScience 58:139 - 150. http://dx.doi.org/10.1641/B580208

Rassool, C., and J. Thorne. 2001. A timeline for District Six: a parallel text. in C. Rassool and S. Prosalendis. Recalling Community in Cape Town. District Museum Foundation, Cape Town, South Africa.

Rebelo, A. G., P. Holmes, C. Dorse, and J. Wood, 2011. Impacts of urbanization in a biodiversity hotspot: conservation challenges in Metropolitan Cape Town. South African Journal of Botany 77:20 - 35. http://dx.doi.org/10.1016/j.sajb.2010.04.006

Redham, C. 2011. Social-ecological transformations in urban landscapes - a historical perspective. in J. Niamela, J. Breuste, T. Elmqvist, G. Guntenspergen, P. James and N. MacIntyre, (editors). Urban Ecology: Patterns, Processes and Applications. Oxford Biology, Oxford, U.K.

Richardson, D. M.., I. A. W. MacDonald, P. M. Holmes, and R. M. Cowling. 1992. Plant and Animal Invasions. in R. M. Cowling, (editor). The Ecology of Fynbos, Nutrients, Fire and Diversity. Oxford University Press, Cape Town, South Africa.

Rosenthal, E. 1966. Three hundred years of the castle at Cape Town. Ecclesia Printing Works, Cape Town.

Rothstein, B. 2000. Trust, social dilemmas, and collective memories. Journal of Theoretical Politics 12 (4):447 - 501. http://dx.doi.org/10.1177/0951692800012004007

Ross, R. 1984. The Occupations of Slaves in Eighteenth Century Cape Town. in C. Saunders and H. Phillips, (editors). Studies in the History of Cape Town, Volume 2. Centre for African Studies, University of Cape Town, South Africa. 
Shaughnessy, G. L. 1980. Historical ecology of alien woody plants in the vicinity of Cape Town, South Africa. Unpublished $\mathrm{PhD}$ thesis, University of Cape Town, Cape Town.

Simmons, I. G. 1993. Environmental history: a concise introduction. Blackwell Publishers, Oxford, U.K.

Skead, C. J. 1980. Historical Mammal Incidence in the Cape Province. Volume 1. The Department of Nature and Environmental Conservation of the Provincial Administration of the Cape of Good Hope, Cape Town, South Africa.

Smith, A. B. 1983. Prehistoric pastoralism in the Southwestern Cape, South Africa, Cape Town. World Archaeology 15 (1):79-89. http://dx.doi.org/10.1080/00438243.1983.9979886

Southworth, B. 2010. Making public space in $21^{\text {st }}$ century Cape Town: - an idealistic planning construct or a catalytic city building project? in E Pieterse, (editor). Counter Currents Experiments in Sustainability in the Cape Town Region. Jacana Media, Cape Town, South Africa.

The Cape Town Partnership. 2010. Reclaim Camissa - the place of sweet waters. [Online] URL: http://www. capetownpartnership.co.za/tag/reclaim-camissa [accessed May 2011]

Taylor, H. C. 1977. Aspects of the ecology of the Cape of Good Hope Nature Researve in relation to fire and conservation. in H. A. Mooney and C. E. Conrad, (editors). Proceedings of the Symposium on the Environmental Consequences of Fire and Fuel Management in Mediterranean Ecosystem. USDA Forest Service General Technical Report, WO-3, USA.

Trinder-Smith, T. H., A. T. Lombard, and M. D. Picker. 1996. Reserve scenarios for the Cape Peninsula: high-, middle- and low-road options for conserving the remaining biodiversity. Biodiversity and Conservation, 5:649 - 669. http://dx.doi.org /10.1007/BF00137613

Lannas, K. S. M., and J. K. Turpie. 2009. Valuing the provisioning services of wetlands: contrasting a rural wetland in Lesotho with a peri-urban wetland in South Africa. Ecology and Society 14(2): 18. [online] URL: http://www.ecologyand society.org/vol14/iss2/art18/.

Turpie, J. K., C. Marais, and J. N. Blignaut. 2008. The Working for Water programme: Evolution of a payments for ecosystem services mechanism that addresses both poverty and ecosystem service delivery in South Africa. Ecological Economics, 65:788 - 798. http://dx.doi.org/10.1016/j.ecoleco n.2007.12.024

Van Wilgen, B. W. 2012. Evidence, perceptions, and tradeoffs associated with invasive alien plant control in the Table Mountain National Park, South Africa. Ecology and Society 17(2): 23. http://dx.doi.org/10.5751/ES-04590-170223
Wagener, F. J. 1957.Rondebosch down the years. Cape Times, Cape Town, South Africa

Walker, B. H., J. M. Anderies, A. P. Kinzig, and P. Ryan. 2006. Exploring resilience in social-ecological systems through comparative studies and theory development: Introduction to the special issue. Ecology and Society, 11 (1):12. [online] URL: http://www.ecologyandsociety.org/vol11/ iss1/art12/.

Wilby, R.L. and G.L.W. Perry. 2006. Climate change, biodiversity and the urban environment: a critical review based on London, UK. Progress in Physical Geography 30 (1): 73 -98 http://dx.doi.org/10.1191/0309133306pp470ra

Worden, N., E. van Heyningen. And V. Bickford-Smith. 1998. Cape Town the Making of a City. David Philip Publishers, Cape Town

Yeld, J, and M. Baker. 2004. Mountains in the sea: Table Mountain to Cape Point: an interpretive guide to the Table Mountain National Park. SA National Parks, Pretoria, South Africa. 